\title{
Relationship between insulin-like growth factor-1 (IGF-1) concentrations and body trait measurements and climatic factors in prepubertal goat kids
}

\author{
Erkan Pehlivan \\ Department of Animal Science, Faculty of Agriculture, Ankara University, Ankara, 06110, Turkey \\ Correspondence: Erkan Pehlivan (pehlivan@agri.ankara.edu.tr)
}

Received: 31 August 2018 - Revised: 5 April 2019 - Accepted: 17 April 2019 - Published: 2 May 2019

\begin{abstract}
This study aimed to investigate relations between insulin-like growth factor-1 (IGF-1) concentrations and some body trait measurements (body weight, withers height, rump height, body length, chest depth, chest width, chest girth and cannon bone circumference) and climatic factors in prepubertal male and female White (75\% Saanen and $25 \%$ Kilis goat) and Angora goat kids. For this purpose, blood samples were regularly taken from the vena jugularis, and body trait measurements were regularly carried out (every $15 \mathrm{~d}$ for 5 months) on each kid. The IGF-1 analysis on the blood serum was performed using the enzyme immunoassay (EIA) method. Climatic values and the length of the photoperiod were obtained from the Turkish State Meteorological Service for the experimental period, and the temperature-humidity index (THI) was calculated using these values. Statistical analysis showed that the IGF-1 concentrations were higher $(P<0.05)$ in female White goat kids. Furthermore, differences in IGF-1 concentrations were found $(P<0.05)$ between periods and between the gender groups for both the White and the Angora goat kids. Moreover, the difference between the IGF-1 concentrations between genders was higher $(P<0.05)$ in White goat kids. Additionally, positive and significant correlations were found between IGF-1 concentrations and some body trait measurements in prepubertal kids, except for in female White goat kids. In summary, it was found that there was a significant relationship between IGF-1 concentrations and growth characteristics of the goat kids. Furthermore, IGF-1 concentrations in the goat kids were significantly influenced by climatic factors such as photoperiod, temperature and the temperature-humidity index, with the release of IGF-1 increasing due to increases in the photoperiod and the environmental temperature.
\end{abstract}

\section{Introduction}

Insulin-like growth factors (IGFs) are one of the most important compounds that influence metabolism in animals. IGFs are a family of polypeptides that carry out metabolic and mitogenic activities. The most potent mitogenic IGF peptide is insulin-like growth factor-1 (IGF-1), a basic polypeptide of 70 amino acids directed by growth hormone under normal physiological conditions (Buonomo et al., 1988). IGF-1 is mainly produced in the liver in addition to being produced by the environmental tissues such as the skin, ovary, placenta, breast and bone as autocrine/paracrine (Hashizume et al., 2000; Basturk, 2007). The bioactivity of IGF-1 is achieved by specific insulin-like growth factor binding proteins (IGFBPs) with high affinity (Obese et al., 2008).
IGF-1 plays an important role in various physiological processes such as reproduction, growth, lactation and the health of the organism (McGuire et al., 1992). IGF-1 is involved in the growth and function of almost every organ in the body (Rasouli et al., 2017). The predominant physiological effect of IGF-1 is the stimulation of postnatal body growth. In addition, IGF-1 can regulate the synthesis of whole body protein, the uptake of glucose by peripheral tissues and the regulation of lipid metabolism (Hadsell et al., 2002).

IGF-1 is secreted nonpulsatile, and the secretion level of IGF-1 is phenotypically correlated with the live weight and growth rate in cattle, pigs, sheep and chickens (Bishop et al., 1989). In addition, it has been reported that IGF-1 concentrations in farm animals are significantly affected by envi- 
ronmental factors (Sarko et al., 1994). As a matter of fact, Spicer et al. (1994) and Dahl et al. (1997) reported that photoperiod and IGF-1 concentration were positively correlated, Richards et al. (1995) reported a negative correlation between environmental temperature and IGF-1 concentration, Moyes et al. (2003) reported that plasma IGF-1 concentrations decreased when animals were in negative energy balance during the postpartum period, Squires (2003) reported that short-term stress reduced IGF-1 secretion, and Magistrelli et al. (2005) reported that energy and protein contents of rations are directly related to the plasma IGF-1 concentration. However, studies regarding the association of IGF-1 concentrations with growth traits and climatic factors have mainly been carried out on farm animal species other than goats. From this point on, in this study, the relationship between IGF-1 concentrations and some body trait measurements and environmental factors such as temperature and photoperiod are investigated in prepuberty period in male and female kids from two goat breeds that have different growth rates (Cengiz et al., 1995; Erol et al., 2014); this difference is due to the fact that the Angora goat is a fiber goat and the White goat is a milk goat.

\section{Materials and methods}

\subsection{Experimental animals, location and management}

This study was carried out on 13 White goat $(75 \%$ Saanen and $25 \%$ Kilis goat) kids and 12 Angora goat kids raised in the Animal Husbandry Station $\left(39^{\circ} 57^{\prime} 42.5^{\prime \prime} \mathrm{N}\right.$, $\left.32^{\circ} 51^{\prime} 56.2^{\prime \prime} \mathrm{E}\right)$ at the Ankara University, Faculty of Agriculture, Department of Animal Science. All of the goat kids were clinically healthy. The animals were housed in shaded pens with their dams, and natural light from windows and a door was allowed to pass through to the pens. The goat kids were allowed to receive milk from their dams during the experimental period, and from 2 weeks old they were they were fed concentrate feed and alfalfa hay ad libitum. Experimental feeds were collected during the experimental period and analyzed for chemical composition. Dry matter, crude protein, crude fiber, crude ash and crude fat in feeds were analyzed according to the AOAC Official Methods of Analysis (AOAC, 2000). Neutral detergent fibre (NDF) and acid detergent fibre (ADF) were measured according to the methods described by Van Soest et al. (1991). The metabolizable energy (ME) of forage and concentrate mix was calculated according to the Turkish Standards Institute (TSE, 1991). The concentrated feed composition and ME was as follows: dry matter (DM) comprised $91 \%$, crude protein (CP) comprised $18.05 \%$, crude fiber (CF) comprised $8 \%$, crude ash comprised $7.5 \%$ and ether extract (EE) comprised $3.5 \%$; the ME was $2615 \mathrm{Kcal} \mathrm{kg}^{-1}$. The alfalfa composition and ME was as follows: DM comprised $91.5 \%$, CP comprised $13.0 \%$, CF comprised $34.0 \%$, crude ash comprised $8.29 \%$, EE comprised $1.00 \%$, ADF comprised $8.0 \%$, NDF com- prised $49.0 \%$; the ME was $2000.22 \mathrm{kcal} \mathrm{kg}^{-1}$. Fresh water was always available to the goat kids. Management of experimental goat kids did not interfere with the general operation of the station, and the study was conducted within standard ethical norms. Some properties of experimental goat kids are shown in Table 1.

\subsection{Blood collection and IGF-1 analysis}

During the experimental period, the first samples (Period 1) were taken $14-15 \mathrm{~d}$ after birth, and samples (periods 2-10) were the taken at $15 \mathrm{~d}$ intervals for 5 months. On sampling days, blood samples were regularly taken from the vena jugularis of each goat kid using vacuum containers without anticoagulant (VACUETTE ${ }^{\circledR}$ TUBE $8 \mathrm{~mL}$ Z Serum Sep Clot Activator). The blood samples were centrifuged at $4000 \times g$ for $5 \mathrm{~min}$, and the serum was stored at $-20^{\circ} \mathrm{C}$ until the analysis was carried out. IGF-1 concentrations were determined in the blood serum using a commercial ELISA kit (Fine Test Goat IGF-1 Cat. no. EG0002). The intra- and inter-assay coefficients of variation were $<8 \%$ and $<10 \%$, respectively. The least detectable concentration was $14 \mathrm{ng} \mathrm{mL}^{-1}$.

\subsection{Measurement of body traits}

With respect to body trait measurements, the body weight (BW), withers height (WH), rump height (RH), body length (BL), chest depth (CD), chest width (CW), chest girth (CG) and cannon bone circumference (CBC) of each kid were regularly measured on the same sampling days. BW was measured using a commercial hanging scale $( \pm 10 \mathrm{~g})$. A measuring tape was used to measure the height, length, depth and width of the goat kids, whereas other body measurements were taken using a flexible tape measure. All measurements were taken by the same operator and followed the methodology of Herrera et al. (1996).

\subsection{Climatic values, the temperature-humidity index (THI) and the photoperiod}

Climatic values and the photoperiod were obtained from the Turkish State Meteorological Service (Anonymous, 2016) in order to estimate the severity of heat stress during the experimental period. The temperature-humidity index (THI) was calculated using the following equation, reported by Marai et al. (2001) for sheep and goats:

$$
\begin{aligned}
& \mathrm{THI}=\mathrm{db}^{\circ} \mathrm{C}-\{(0.31-0.31 \mathrm{RH} / 100) \\
& \left.\left(\mathrm{db}^{\circ} \mathrm{C}-14.4\right)\right\},
\end{aligned}
$$

where $\mathrm{db}^{\circ} \mathrm{C}$ is the dry bulb temperature $\left({ }^{\circ} \mathrm{C}\right)$ and $\mathrm{RH}$ is the relative humidity $(\mathrm{RH} \%) / 100$. The values obtained indicate the following: $<22.2$ signifies the absence of heat stress; 22.2 to $<23.3$ represents moderate heat stress: 23.3 to $<25.6$ represents severe heat stress and 25.6 and above represents extreme severe heat stress 
Table 1. Some properties of the experimental goat kids.

\begin{tabular}{llrrrr}
\hline Breed & Gender & $n$ & $\begin{array}{r}\text { Average birth } \\
\text { weight }(\mathrm{kg})\end{array}$ & $\begin{array}{r}\text { Average age at the beginning } \\
\text { of experiment (days) }\end{array}$ & $\begin{array}{r}\text { Average live weights at the } \\
\text { beginning of experiment }(\mathrm{kg})\end{array}$ \\
\hline White goat $(n=13)$ & Male & 7 & 3.06 & 14 & 6.53 \\
& Female & 6 & 3.10 & 15 & 6.51 \\
\hline \multirow{2}{*}{ Angora goat $(n=12)$} & Male & 7 & 2.91 & 15 & 5.51 \\
& Female & 5 & 2.50 & 14 & 4.39 \\
\hline
\end{tabular}

Table 2. Average climatic values, the temperature-humidity index (THI) and the length of the photoperiod during the experimental period.

\begin{tabular}{lrrrr}
\hline Periods* & $\begin{array}{r}\text { Average } \\
\text { temperature } \\
\left({ }^{\circ} \mathrm{C}\right)\end{array}$ & $\begin{array}{r}\text { Average } \\
\text { humidity } \\
(\%)\end{array}$ & THI & $\begin{array}{r}\text { Photoperiod } \\
\text { (hour:min) }\end{array}$ \\
\hline 1 & 10.8 & 51.0 & 11.4 & $13: 18$ \\
2 & 18.5 & 31.5 & 17.6 & $13: 50$ \\
3 & 13.9 & 45.9 & 14.0 & $14: 20$ \\
4 & 15.0 & 58.2 & 14.9 & $14: 43$ \\
5 & 17.1 & 78.5 & 17.0 & $14: 58$ \\
6 & 18.3 & 65.6 & 17.9 & $15: 01$ \\
7 & 23.7 & 50.1 & 22.3 & $14: 52$ \\
8 & 27.4 & 35.6 & 24.8 & $14: 31$ \\
9 & 26.1 & 43.6 & 24.1 & $14: 03$ \\
10 & 24.2 & 62.7 & 23.1 & $13: 33$ \\
\hline
\end{tabular}

* The first samples (Period 1) were taken 14-15d after birth, and the other samples (periods $2-10$ ) were the taken at $15 \mathrm{~d}$ intervals.

(Marai et al., 2007).

In addition, the average climatic values, the THI index values and the photoperiod lengths are shown in Table 2.

\subsection{Statistical analysis}

Data were analyzed by a mixed model in SAS (2017) using repeated measurement analysis with breed, gender and period as fixed effects and the live weight of the animal at the beginning of the experiment as the covariate. IGF-1 concentration differences within and between groups and their interactions were evaluated. Multiple comparisons were made using a Tukey test if significance was indicated by the analysis of variance. Correlation coefficients (Pearson) between IGF1 concentrations and some body trait measurements were calculated according to the CORR procedure in SAS (2017). Results are shown as the mean \pm standard error $(\bar{X} \pm S \bar{x})$, and the significance level was set at $\alpha=0.05$.

\section{Results}

\subsection{Climatic values during the experimental period}

Patterns of climatic values during the experiment period are shown in Fig. 1. As seen from Fig. 1, the photoperiod values increased until Period 6, the THI and temperature values increased until Period 8 and then they all gradually decreased thereafter. It has been determined that the experimental kids were heat stressed during the last periods (from Period 6 to Period 10) of the experiment (Table 2).

\subsection{IGF-1 concentrations in prepubertal goat kids}

IGF-1 concentrations in experimental kids progressively increased until Period 8 and then progressively decreased until end of the experiment (Fig. 2); the differences in the IGF1 concentrations between the periods were found to be statistically significant $(P<0.05$; Table 3$)$. Significant differences were found $(P<0.05)$ with respect to IGF-1 concentrations between female and male kids in White goat kids, whereas no significant differences between female and male kids were observed in Angora goat kids (regarding IGF-1 concentrations). Differences between the same genders from different breeds were also found to be statistically important $(P<0.05)$.

\subsection{Some body trait measures in prepubertal goat kids}

Periodic mean values of some body trait measures for White and Angora goat kids are shown in Tables 4 and 5, respectively. An almost linear increase was observed in all of the body trait measures in all of goat kids examined during the experimental period. When the body weights of kids at the end of the experiment were compared with their birth weights, it was found that White goat kids grew more than Angora goat kids, and male kids grew more than female kids.

\subsection{Correlations between IGF-1 concentrations and some body trait measures in prepubertal goat kids}

Phenotypic correlations between IGF-1 and some body trait measures in White goat and Angora goat kids are shown in Table 6. Correlations between IGF-1 and some body trait measures were not found to be statistically significant 


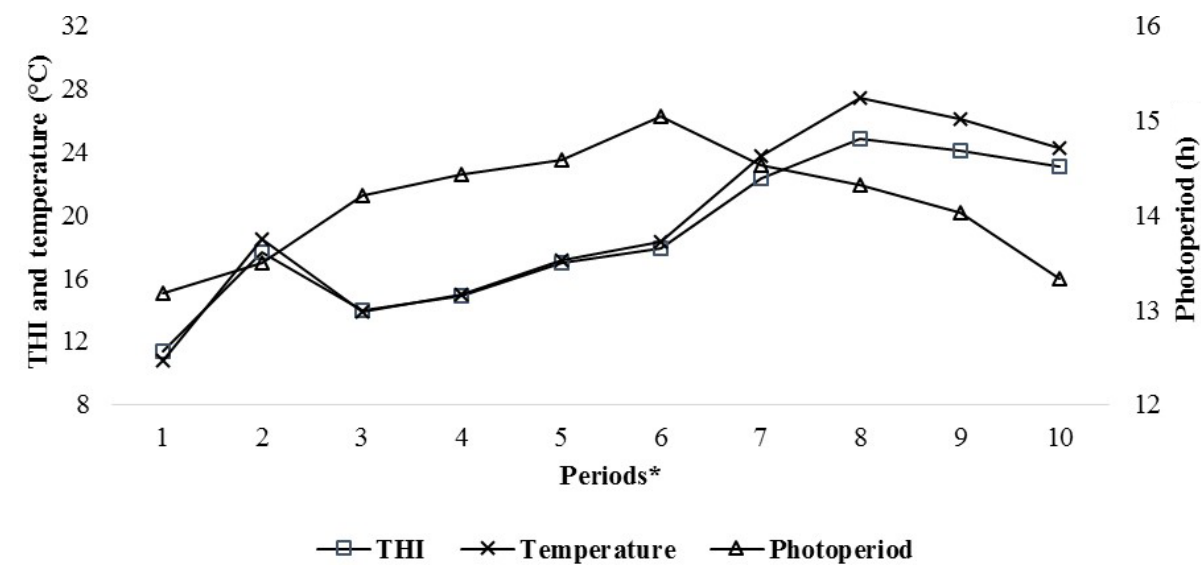

Figure 1. Changes in the average temperature, the temperature-humidity index (THI) and the photoperiod during the experimental periods. * The first samples (Period 1) were taken 14-15 d after birth, and the other samples (periods 2-10) were then carried out at $15 \mathrm{~d}$ intervals.

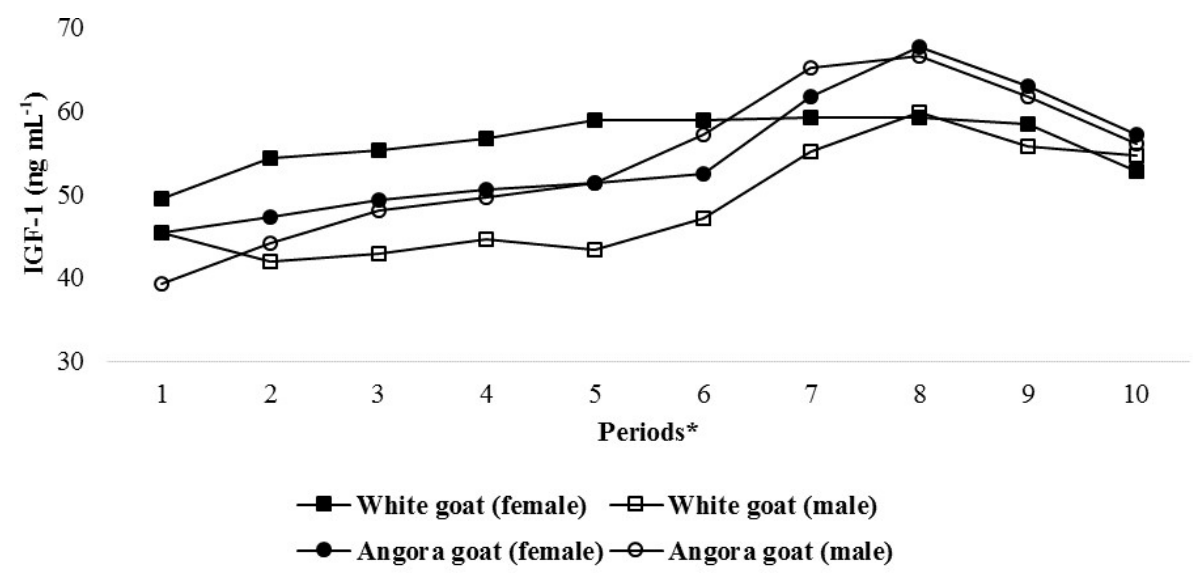

Figure 2. Changes in IGF-1 concentrations of kids during the experimental periods. ${ }^{*}$ The first samples (Period 1$)$ were taken $14-15 \mathrm{~d}$ after birth, and the other samples (periods 2-10) were then carried out at $15 \mathrm{~d}$ intervals.

$(P>0.05)$ in female White goat kids, whereas these correlations (except $\mathrm{CBC}$ ) were found to be statistically significant $(P<0.01)$ in male White goat kids. In Angora goat kids, IGF-1 concentrations were correlated with $\mathrm{BW}(P<$ $0.01)$, WH $(P<0.01)$, RH $(P<0.01)$, BL $(P<0.01)$, CD $(P<0.01)$, CW $(P<0.01), \mathrm{CG}(P<0.01)$ and $\mathrm{CBC}$ (for females: $P<0.01$; for males $P<0.05$ ).

\section{Discussion}

This study was carried out from mid-April to mid-August, which comprised a range of seasonal variations regarding factors such as the THI, the temperature and the photoperiod that could affect the IGF-1 concentrations of the experimental goat kids. Thus, the effects of climatic factors such as temperature, heat stress and photoperiod on IGF1 concentrations of experimental kids may have been confounded with one another. Because the experiment was not carried out under controlled photoperiod/temperature condi- tions, it was not clear which climatic factors more heavily impacted the IGF-1 concentrations of the prepubertal kids. However, in this study, the pattern of IGF-1 concentrations in the kids was similar to the change in the photoperiod during the experimental period (Fig. 2). It has also been previously reported that IGF-1 concentrations in farm animals are significantly affected by environmental factors (Sarko et al., 1994). In many previous studies, especially those conducted on ruminants, it is suggested that seasonal changes in IGF1 concentrations are mainly driven by photoperiod (Dahl et al., 2000). In addition, it has been reported that the photoperiod has a significant effect on IGF-1 concentrations in goats (Flores et al., 2015, 2018; Hernández et al., 2016). Similarly, in a study carried out on male red deer, it was reported that melatonin implantation, which had "short-day effects", suppressed IGF-1 release (Suttie et al., 1992). Another study on cattle reported that the IGF-1 levels of cattle in a $16 \mathrm{~h}$ light per day group for 4 months were considerably higher than those in an $8 \mathrm{~h}$ light per day group (Spicer et al., 1994). 
Table 3. Least squares means and standard errors $(\bar{X} \pm S \bar{x})$ of IGF-1 concentrations in White goat and Angora goat kids.

\begin{tabular}{lrr|rr}
\hline Periods* & \multicolumn{2}{c|}{ White goat } & \multicolumn{2}{c}{ Angora goat } \\
\cline { 2 - 5 } & Female $(n=6)$ & Male $(n=7)$ & Female $(n=5)$ & Male $(n=7)$ \\
\hline 1 & $50.98 \pm 1.95^{\mathrm{XaA}}$ & $46.94 \pm 1.81^{\mathrm{XabA}}$ & $42.46 \pm 2.25^{\mathrm{aB}}$ & $38.59 \pm 1.77^{\mathrm{aB}}$ \\
2 & $55.78 \pm 2.49^{\mathrm{XbA}}$ & $43.50 \pm 2.31^{\mathrm{YaA}}$ & $44.32 \pm 2.82^{\mathrm{aB}}$ & $43.46 \pm 2.28^{\mathrm{bA}}$ \\
3 & $56.78 \pm 3.30^{\mathrm{XabA}}$ & $44.37 \pm 3.06^{\mathrm{YaA}}$ & $46.33 \pm 3.69^{\mathrm{abA}}$ & $47.45 \pm 3.04^{\mathrm{cA}}$ \\
4 & $58.15 \pm 3.23^{\mathrm{XbA}}$ & $46.07 \pm 3.00^{\mathrm{YaA}}$ & $47.65 \pm 3.61^{\mathrm{abB}}$ & $48.91 \pm 2.97^{\mathrm{cdA}}$ \\
5 & $60.36 \pm 3.26^{\mathrm{XbA}}$ & $44.81 \pm 3.02^{\mathrm{YaA}}$ & $48.34 \pm 3.64^{\mathrm{abB}}$ & $50.63 \pm 3.00^{\mathrm{cdA}}$ \\
6 & $60.38 \pm 4.21^{\mathrm{XabA}}$ & $48.68 \pm 3.90^{\mathrm{XabcA}}$ & $49.46 \pm 4.67^{\mathrm{abA}}$ & $56.49 \pm 3.88^{\mathrm{efA}}$ \\
7 & $60.73 \pm 4.63^{\mathrm{XabA}}$ & $56.66 \pm 4.29^{\mathrm{XdA}}$ & $58.75 \pm 5.12^{\mathrm{cdA}}$ & $64.56 \pm 4.27^{\mathrm{gA}}$ \\
8 & $60.69 \pm 3.94^{\mathrm{XbA}}$ & $61.34 \pm 3.65^{\mathrm{XdA}}$ & $64.58 \pm 4.37^{\mathrm{dA}}$ & $65.93 \pm 3.63^{\mathrm{gA}}$ \\
9 & $59.82 \pm 3.84^{\mathrm{XbA}}$ & $57.27 \pm 3.56^{\mathrm{XdA}}$ & $59.93 \pm 4.27^{\mathrm{cdA}}$ & $61.02 \pm 3.54^{\text {fgA }}$ \\
10 & $54.30 \pm 3.65^{\mathrm{XabA}}$ & $56.14 \pm 3.39^{\mathrm{XcdA}}$ & $54.21 \pm 4.07^{\mathrm{bcA}}$ & $55.35 \pm 3.37^{\mathrm{deA}}$ \\
\hline
\end{tabular}

Notes: a, b, c, d, e, f, g: Means in the same column with different superscripts differ significantly at $p<0.05$. X, Y: Means in the same row with different superscripts differ significantly at $p<0.05$ (in the comparison of the genders within breeds). A, B: Means in the same row with different superscripts differ significantly at $p<0.05$ (in the comparison of the same gender between breeds). ${ }^{*}$ The first samples (Period 1) were taken 14-15 d after birth, and the other samples (periods 2-10) were then carried out at $15 \mathrm{~d}$ intervals.

Table 4. Periodic mean values $(\bar{X} \pm S \bar{x})$ of some body trait measures in White goat kids.

\begin{tabular}{|c|c|c|c|c|c|c|c|c|c|}
\hline Periods* & Gender & BW (kg) & $\mathrm{WH}(\mathrm{cm})$ & $\mathrm{RH}(\mathrm{cm})$ & $\mathrm{BL}(\mathrm{cm})$ & $\mathrm{CD}(\mathrm{cm})$ & $\mathrm{CW}(\mathrm{cm})$ & $\mathrm{CG}(\mathrm{cm})$ & $\mathrm{CBC}(\mathrm{cm})$ \\
\hline \multirow[t]{2}{*}{1} & $\mathrm{~F}$ & 6.52 & $34.83 \pm 0.87$ & $34.50 \pm 0.92$ & $35.17 \pm 0.95$ & 14.50 & $=0.43$ & $43.00 \pm 1.61$ & 6.30 \\
\hline & M & $6.53 \pm$ & $34.86 \pm$ & $5.14 \pm 0.86$ & 36.14 & $13.71=$ & 0.26 & $43.00 \pm 1.25$ & 6.79 \\
\hline \multirow[t]{2}{*}{2} & $\mathrm{~F}$ & 5 & 3 & & & & & & \\
\hline & M & $7.86 \pm 0.84$ & $40.57 \pm 0.57$ & $40.86 \pm 0.59$ & $37.86 \pm 1.50$ & $14.57 \pm 0.48$ & $8.43 \pm 0.72$ & $46.29 \pm 2.00$ & $6.54 \pm 0.15$ \\
\hline \multirow[t]{2}{*}{3} & $\mathrm{~F}$ & $1.37=$ & 44.00 & $44.50=$ & 42.00 & 15.8 & 11.0 & 53.00 & 6.5 \\
\hline & M & $10.41 \pm 0.97$ & $44.71 \pm 1.04$ & $45.00 \pm 1.07$ & $41.00 \pm 1.66$ & $15.57 \pm 0.48$ & $9.86 \pm 0.70$ & $50.93 \pm 2.21$ & $6.73 \pm 0.20$ \\
\hline \multirow[t]{2}{*}{4} & $\mathrm{~F}$ & & & & & & 12.5 & & \\
\hline & M & $12.43 \pm 1.46$ & $49.14 \pm 1.68$ & $49.57 \pm 2.06$ & $44.57 \pm 2.06$ & $16.93 \pm 0.64$ & $11.21 \pm$ & $53.57=$ & $6.86=$ \\
\hline \multirow[t]{2}{*}{5} & $\mathrm{~F}$ & $16.64 \pm 0.75$ & $51.00 \pm 0.68$ & $51.17 \pm 1.08$ & $49.50 \pm 0.76$ & $20.00 \pm 0.37$ & $12.83 \pm 0.48$ & $60.25 \pm 1.35$ & \\
\hline & M & $15.17 \pm 1.87$ & $52.86 \pm 1.75$ & $50.86 \pm 1.75$ & $48.14 \pm 2.19$ & $19.36 \pm 0.82$ & $11.86 \pm 0.63$ & $57.00 \pm 2.09$ & $7.07 \pm 0.27$ \\
\hline \multirow[t]{2}{*}{6} & $\mathrm{~F}$ & $17.78 \pm 0.77$ & $51.83 \pm 0.54$ & $52.00 \pm 0.82$ & $50.83 \pm 0.60$ & $20.67 \pm 0.42$ & $13.58 \pm 0.33$ & $60.67 \pm 1.44$ & $7.20 \pm 0.10$ \\
\hline & M & $17.54 \pm 1.99$ & $53.29 \pm 1.67$ & $52.00 \pm 1.50$ & $49.14 \pm 2.18$ & $21.00 \pm 0.93$ & $12.79 \pm 0.60$ & $57.93 \pm 2.08$ & $7.44 \pm 0.30$ \\
\hline \multirow[t]{2}{*}{7} & $\mathrm{~F}$ & $19.04 \pm 0.81$ & $54.00 \pm 0.37$ & $55.33 \pm 0.21$ & $50.83 \pm 0.40$ & $21.83 \pm 0.87$ & $12.83 \pm 0.40$ & $63.17 \pm 1.35$ & $7.37 \pm 0.13$ \\
\hline & M & $19.29 \pm 2.16$ & $55.43 \pm 2.19$ & $56.14 \pm 1.83$ & $50.00 \pm 2.23$ & $21.43 \pm 0.72$ & $12.43 \pm 0.81$ & $61.86 \pm 2.77$ & $7.49 \pm 0.32$ \\
\hline \multirow[t]{2}{*}{8} & $\mathrm{~F}$ & $19.61 \pm 1.08$ & $55.67 \pm 1.20$ & $57.00 \pm 0.82$ & $52.50 \pm 0.76$ & $21.50 \pm 0.56$ & $12.83 \pm 0.48$ & $64.33 \pm 1.50$ & $7.27 \pm 0.13$ \\
\hline & M & $20.60 \pm 2.40$ & $57.57 \pm 2.26$ & $58.29 \pm 1.92$ & $53.14 \pm 2.67$ & $22.00 \pm 0.93$ & $12.86 \pm 0.70$ & $62.00 \pm 2.96$ & $7.31 \pm 0.43$ \\
\hline \multirow[t]{2}{*}{9} & $\mathrm{~F}$ & $20.94 \pm 1$ & $56.67 \pm$ & $59.00=$ & 52.33 & 22.33 & 13.17 & 17 & $7.27 \pm 0.15$ \\
\hline & M & $21.92 \pm 2.68$ & $58.57 \pm 2.00$ & $59.00 \pm 1.98$ & $55.00 \pm 3.54$ & $22.43 \pm 0.95$ & $12.43 \pm 0.81$ & $65.64 \pm 3.76$ & $7.39 \pm 0.47$ \\
\hline \multirow[t]{2}{*}{10} & $\mathrm{~F}$ & 2 & 57.33 & 60.50 & 55.17 & 22.50 & $13.1^{\prime}$ & 66.6 & 7.5 \\
\hline & M & $23.42 \pm 2.90$ & $59.14 \pm 2.19$ & $60.14 \pm 2.02$ & $54.12 \pm 2.42$ & $22.71 \pm 0.97$ & $13.29 \pm 0.99$ & $66.29 \pm 2.90$ & $7.69 \pm 0.33$ \\
\hline
\end{tabular}

F: female; M: male; BW: body weight; WH: withers height; RH: rump height; BL: body length; CD: chest depth; CW: chest width; CG: chest girth; CBC: cannon bone circumference. ${ }^{*}$ The first samples (Period 1) were taken $14-15 \mathrm{~d}$ after birth, and the other samples (periods $2-10$ ) were then carried out at $15 \mathrm{~d}$ intervals.

Furthermore, in studies investigating the effect of environmental temperature on IGF-1 concentrations in farm animals, Richards et al. (1995) found a negative correlation between environmental temperature and IGF-1 concentrations, and Aggarwal and Upadhyay (2013) reported that IGF-1 concentrations in their study decreased during the summer months.
Similarly, in this study, it can be seen that IGF-1 concentrations of kids started to decrease during periods of high temperature and heat stress (Figs. 1 and 2).

As seen from Tables 4 and 5, all body trait measures increased linearly as the kids grew. However, there were differences both between breeds and between genders in terms of 
Table 5. Periodic mean values $(\bar{X} \pm S \bar{x})$ of some body trait measures in Angora goat kids.

\begin{tabular}{|c|c|c|c|c|c|c|c|c|c|}
\hline Periods* & Gender & BW (kg) & WH (cm) & $\mathrm{RH}(\mathrm{cm})$ & $\mathrm{BL}(\mathrm{cm})$ & $\mathrm{CD}(\mathrm{cm})$ & $\mathrm{CW}(\mathrm{cm})$ & $\mathrm{CG}(\mathrm{cm})$ & $\mathrm{CBC}(\mathrm{cm})$ \\
\hline \multirow[t]{2}{*}{1} & $\mathrm{~F}$ & 4.40 & 0.93 & 29.00 & 29.00 & 12.0 & & 37.00 & 0.13 \\
\hline & M & $5.51 \pm 0.44$ & $32.57 \pm 0.95$ & $32.86 \pm 0.94$ & $32.00 \pm 0.72$ & $12.86 \pm 0.51$ & $7.86 \pm 0.26$ & $39.79 \pm 0.98$ & $6.11 \pm 0.26$ \\
\hline \multirow[t]{2}{*}{2} & $\mathrm{~F}$ & 8 & & د & 6 & 11.0 & & 59 & $5.44 \pm 0.15$ \\
\hline & M & $7.49 \pm 0.62$ & $37.29 \pm 1.08$ & $38.00 \pm 1.23$ & $36.00 \pm$ & $13.86 \pm 0.46$ & $8.71 \pm 0.47$ & $44.64 \pm 1.16$ & 6.20 \\
\hline \multirow[t]{2}{*}{3} & $\mathrm{~F}$ & 9 & 38 & 38 & 1 & 0 & 9. & 463 & \\
\hline & M & $9.73 \pm 0.91$ & $42.57 \pm 1.21$ & $42.71 \pm 1.23$ & $39.00 \pm 0.98$ & $15.29 \pm 0.52$ & $10.00 \pm 0.44$ & $50.07 \pm 1.37$ & 6.40 \\
\hline \multirow[t]{2}{*}{4} & $\mathrm{~F}$ & $10.06 \pm 0.96$ & $43.60 \pm 0.51$ & $43.60 \pm 0.51$ & $40.00 \pm 1.34$ & $15.60 \pm 0.93$ & $10.80 \pm 0.49$ & $49.40 \pm 2.20$ & $5.88 \pm 0.21$ \\
\hline & $\mathrm{M}$ & $12.90 \pm 0.89$ & $48.00 \pm 1.29$ & $48.00 \pm 1.27$ & $42.00 \pm 1.11$ & $17.07 \pm 0.71$ & $11.64 \pm 0.37$ & $53.86 \pm 1.35$ & $6.66 \pm 0.18$ \\
\hline \multirow[t]{2}{*}{5} & $\mathrm{~F}$ & $11.46 \pm 1.12$ & $46.40 \pm 1.36$ & $46.40 \pm 1.36$ & $42.80 \pm 1.36$ & $15.50 \pm 0.59$ & $11.10 \pm 0.33$ & $51.80 \pm 2.31$ & $6.20 \pm 0.31$ \\
\hline & M & $15.00 \pm 1.08$ & $49.86 \pm 1.53$ & $51.43 \pm 1.31$ & $46.71 \pm 1.17$ & $18.43 \pm 0.69$ & $12.14 \pm 0.32$ & $56.71 \pm 1.20$ & $6.93 \pm 0.28$ \\
\hline \multirow[t]{2}{*}{6} & $\mathrm{~F}$ & $12.72 \pm 1.34$ & $47.20 \pm 1.53$ & $47.60 \pm 1.50$ & $44.40 \pm 1.69$ & $16.90 \pm 0.78$ & $11.90 \pm 0.51$ & $51.90 \pm 2.33$ & $6.36 \pm 0.30$ \\
\hline & M & $16.24 \pm 1.26$ & $50.86 \pm 1.50$ & $52.00 \pm 1.51$ & $47.29 \pm 1.23$ & $19.86 \pm 0.51$ & $12.79 \pm 0.43$ & $57.07 \pm 1.21$ & $7.34 \pm 0.28$ \\
\hline \multirow[t]{2}{*}{7} & $\mathrm{~F}$ & $13.36 \pm 1.28$ & $48.40 \pm 1.86$ & $49.60 \pm 1.99$ & $47.20 \pm 0.37$ & $18.40 \pm 0.68$ & $12.10 \pm 0.68$ & $55.60 \pm 2.50$ & $6.16 \pm 0.12$ \\
\hline & M & $17.29 \pm 1.41$ & $53.57 \pm 2.01$ & $54.57 \pm 1.60$ & $48.71 \pm 0.97$ & $20.29 \pm 0.47$ & $12.43 \pm 0.43$ & $59.57 \pm 1.56$ & $6.87 \pm 0.23$ \\
\hline \multirow[t]{2}{*}{8} & $\mathrm{~F}$ & $14.31 \pm 1.46$ & $48.80 \pm 1$ & $50.20 \pm 1.83$ & $46.80 \pm 1.98$ & $17.60 \pm 0.93$ & $11.80 \pm 0.80$ & & \\
\hline & M & $18.46 \pm 1.69$ & $54.00 \pm 2.43$ & $55.00 \pm 2.17$ & $49.71 \pm 1.52$ & $20.14 \pm 0.63$ & $12.43 \pm 0.43$ & $61.07 \pm 1.46$ & $6.91 \pm 0.28$ \\
\hline \multirow[t]{2}{*}{9} & $\mathrm{~F}$ & $14.44 \pm$ & $49.40 \pm 1.40$ & $50.60 \pm$ & 48.00 & $17.40=$ & 11.40 & 55.60 & 6.1 \\
\hline & M & $19.17 \pm 1.91$ & $54.29 \pm 2.83$ & $56.57 \pm 2.47$ & $51.29 \pm 2.02$ & $20.86 \pm 0.77$ & $13.14 \pm 0.67$ & $62.29 \pm 1.87$ & $7.07 \pm 0.25$ \\
\hline \multirow[t]{2}{*}{10} & $\mathrm{~F}$ & 1 & 49.80 & 5 & 47 & 19.0 & 12.8 & 57.6 & 6.1 \\
\hline & M & $20.74 \pm 2.02$ & $54.71 \pm 2.33$ & $57.29 \pm 2.38$ & $52.29 \pm 1.80$ & $21.00 \pm 0.69$ & $13.29 \pm 0.52$ & $63.86 \pm 1.74$ & $7.03 \pm 1.39$ \\
\hline
\end{tabular}

F: female; M: male; BW: body weight; WH: withers height; RH: rump height; BL: body length; CD: chest depth; CW: chest width; CG: chest girth; CBC: cannon bone circumference. ${ }^{*}$ The first samples (Period 1) were taken $14-15 \mathrm{~d}$ after birth, and the other samples (periods $2-10$ ) were then carried out at $15 \mathrm{~d}$ intervals.

Table 6. Correlation coefficients between IGF-1 and some body trait measures in prepubertal goat kids.

\begin{tabular}{lllrrrrrrrr}
\hline Breeds & Gender & & BW & WH & RH & BL & CD & CW & CG & CBC \\
\hline White goat kids & F & IGF-1 & -0.039 & 0.134 & 0.059 & 0.011 & 0.092 & -0.187 & -0.028 & -0.085 \\
& M & IGF-1 & $0.371^{* *}$ & $0.332^{* *}$ & $0.367^{* *}$ & $0.330^{* *}$ & $0.400^{* *}$ & $0.301^{*}$ & $0.318^{* *}$ & 0.171 \\
\hline \multirow{2}{*}{ Angora goat kids } & F & IGF-1 & $0.700^{* *}$ & $0.648^{* *}$ & $0.678^{* *}$ & $0.737^{* *}$ & $0.680^{* *}$ & $0.521^{* *}$ & $0.691^{* *}$ & $0.448^{* *}$ \\
& M & IGF-1 & $0.541^{* *}$ & $0.590^{* *}$ & $0.620^{* *}$ & $0.634^{* *}$ & $0.593^{* *}$ & $0.590^{* *}$ & $0.606^{* *}$ & $0.246^{*}$ \\
\hline
\end{tabular}

** $P<0.01,{ }^{*} P<0.05$. F: female; M: male; BW: body weight; WH: withers height; RH: rump height; BL: body length; CD: chest depth; CW: chest width; CG: chest girth; CBC: cannon bone circumference.

the growth rate. It is known that IGF-1 concentrations show a positive correlation with skeletal development, protein accumulation and growth rate in farm animals (Bishop et al., 1989). Thus, positive correlations between IGF-1 concentrations and live weight and weight gain have been reported in farm animal species such as cattle, pigs, sheep and poultry (Bishop et al., 1989; Davis and Simmen, 1997). In this study, statistically significant positive correlations were also found between IGF-1 concentrations and some body trait measures in kids, except in female White goat kids (Table 6). The presence of positive and significant correlations between IGF-1 and growth traits is an expected outcome due to the growth and development of prepubertal goat kids; however, these correlations may be negative in adult goats. As a matter of fact, it has been reported that there is a negative correlation between IGF-1 concentrations and body mass in 36 mammalian species, and that high IGF-1 levels allow for cancer growth and thus shorten the animal's life span (Stuart and Page, 2010). However, this result contrasts with the reported negative correlations $(r=-0.56)$ between IGF-1 concentrations and live weight in Angora goat kids (Acuti et al., 2009). In summary, the findings obtained from this study are generally compatible with studies on other mammalian species.

\section{Conclusion}

Results of this study indicate that there is a significant relationship between IGF-1 concentrations and growth characteristics of goat kids. IGF-1 releases in prepubertal goat kids increased due to increases in the photoperiod and environ- 
mental temperature, and statistically significant positive correlations between IGF-1 concentrations and some body trait measures were also found in prepubertal kids.

Data availability. The data sets can be taken from the figures/tables or are available upon request from the corresponding author.

Competing interests. The author declares that there is no conflict of interest.

Acknowledgements. The author would like to thank Gursel Dellal for valuable suggestions on the writing of this paper, Huseyin Polat for carrying out the hormone analysis and Seyrani Koncagul for helping with the statistical analysis. The author is also grateful for their general support in the realization of this study. This research did not receive any specific grants from funding agencies in the public, commercial or not-for-profit sectors.

Review statement. This paper was edited by Manfred Mielenz and reviewed by Huseyin Polat and one anonymous referee.

\section{References}

Acuti, G., Todini, L., Malfatti, A., Antonini, M., Barbato, O., and Trabalza-Marinucci, M.: Effects of field bean (Vicia faba L. var. minor) dietary supplementation on plasma thyroid hormones, insulin, insulin-like growth factor-1 concentrations and mohair characteristics in growing Angora goat kids, J. Anim. Physiol. An. N., 93, 456-466, 2009.

Aggarwal, A. and Upadhyay, R.: Heat Stress and Animal Productivity, https://doi.org/10.1007/978-81-322-0879-2_3, Springer, India, 2013.

Anonymous: Turkish State Meteorological Service, Department of Statistics, Data Set, Ankara (Turkey), 2016.

AOAC: Official Methods of Analysis, 17th Edn., Association of Official Analytical Chemist, Arlington, VA, USA, 2000.

Basturk, E.: Nodüler guatr oluşumunda insülin benzeri büyüme faktörünün (IGF-1) rolü (The role of insulin-like growth factor (IGF-1) in the formation of nodular goiter), Republic of Turkey, Ministry of Health, Dr. Lütfi Kırdar Kartal Training and Research Hospital, Specialist thesis, 2007 (in Turkish).

Bishop, M. D., Simmen, R. C. M., Simmen, F. A., and Davis, M. E.: The relationship of insulin-like growth factor-I with postweaning performance in Angus beef cattle, J. Anim. Sci., 67, 2872-2880, 1989.

Buonomo, F. C., Grohs, D. L., Baile, C. A., and Campion, D. R.: Determination of circulating levels of insulin-like growth factor II (IGF-II) in swine, Domest. Anim. Endocrin., 5, 323-329, 1988.

Cengiz, F., Dellal, G., and Karakaya, A.: Growth and development characteristics in White goat kids, Turk. J. Vet. Anim. Sci., 19, 429-434, 1995.

Dahl, G. E., Elsasser, T. H., Capuco, A. V., Erdman, R. A., and Peters, R. R.: Effects of long day photoperiod on milk yield and circulating insulin-like growth factor-1, J. Dairy Sci., 80, 2784 2789, 1997.

Dahl, G. E., Buchanan, B. A., and Tucker, H. A.: Photoperiodic effects on dairy cattle: A review, J. Dairy Sci., 83, 885-893, 2000.

Davis, M. E. and Simmen, R. C. M.: Genetic parameter estimates for serum insulin-like growth factor I concentration and performance traits in Angus beef cattle, J. Anim. Sci., 75, 317-324, 1997.

Erol, H., Unal, N., Unal, M., and Akcadag, H. I.: Important production traits of Angora goats reared under conservation as a gene resource, Ankara Univ. Vet. Fak. Derg, 61, 211-216, 2014.

Flores, M. J., Delgadillo, J. A., Flores, J. A., Pastor, F. J., Duarte, G., Vielma, J., and Hernández, H.: Artificial long days increase milk production in subtropical lactating goats managed under extensive grazing conditions, J. Agric. Sci., 153, 335-342, 2015.

Flores, M. J., Flores, J. A., Duarte, G., Vielma, J., Delgadillo, J. A., and Hernández, H.: Artificial long-day photoperiod in the subtropics increases body weight in goat kids born in the autumn, Small Ruminant Res., 169, 181-185, 2018.

Hadsell, D. L., Bonnette, S. G., and Lee, A. V.: Genetic manipulation of the IGF-I axis to regulate mammary gland development and function, J. Dairy Sci., 85, 365-377, 2002.

Hashizume, T., Ohtsuki, K., and Matsumoto, N.: Plasma insulinlike growth factor-I concentrations increase during the estrous phase in goats, Domest. Anim. Endocrin., 18, 253-263, 2000.

Hernández, H., Flores, J. A., Delgadillo, J. A., Fernández, I. G., Flores, M. J., Mejía, A., Elizundia, J. M., Bedos, M., Ponce, J. L., and Ramírez, S.: Effects of exposure to artificial long days on milk yield, maternal insulin-like growth factor 1 levels and kid growth rate in subtropical goats, Anim. Sci. J., 87, 484-491, 2016.

Herrera, M., Rodero, E., Gutierrez, M. J., Pena, F., and Rodero, J.M.: Application of multifactorial discriminant analysis in the morphostructural differentiation of Andalusian caprine breeds, Small Ruminant Res., 22, 39-47, 1996.

Magistrelli, D., Valli, A., and Rosi, F.: Insulin and IGF-1 in goat milk: influence of the diet, Ital. J. Anim. Sci., 4, 386-388, 2005.

Marai, I. F. M., Ayyat, M. S., and Abd El-Monem, U. M.: Growth performance and reproductive traits at first parity of New Zealand White female rabbits as affected by heat stress and its alleviation under Egyptian conditions, Trop. Anim. Health Prod., 33, 451462, 2001.

Marai, I. F. M., El-Darawany, A. A., Fadiel, A., and Abdel-Hafez, M. A. M.: Physiological traits as affected by heat stress-a review, Small Ruminant Res., 71, 1-12, 2007.

McGuire, M. A., Vicini, J. L., Bauman, D. E., and Veenhuizent, J. J.: Insulin-like growth factors and binding proteins in ruminants and their nutritional regulation, J. Anim. Sci., 70, 2901-2910, 1992.

Moyes, T. E., Stockdale, C. R., Humphyrs, S., and Macmillan, K. L.: Differences in plasma concentration of insulin-like growth factor-1 between pregnant and nonpregnant dairy cows, Reprod. Fertil. Develop., 15, 22, https://doi.org/10.1071/SRB03Ab22, 2003.

Obese, F. Y., Rablee, A. R., Macmillan, K. L., Egan, A. R., Humphrys, S., and Anderson, G. A.: Variation in plasma concentrations of insulin-like growth factor-I in pasture-fed Holstein cows, J. Dairy Sci., 91, 1814-1821, 2008. 
Rasouli, S., Abdolmohammadi, A., Zebarjadi, A., and Mostafaei, A.: Evaluation of polymorphism in IGF-I and IGFBP-3 genes and their relationship with twinning rate and growth traits in Markhoz goats, Ann. Anim. Sci., 17, 89-103, 2017.

Richards, M. W., Spicer, L. J., and Wettemann, R. P.: Influence of diet and ambient temperature on bovine serum insulin-like growth factor-I and thyroxine: relationships with non-esterified fatty acids, glucose, insulin, luteinizing hormone and progesterone, Anim. Reprod. Sci., 37, 267-279, 1995.

Sarko, T. A., Bishop, M. D., and Davis, M. E.: Relationship of air temperature, relative humidity, precipitation, photoperiod, wind speed and solar radiation with serum insulin-like growth factor I (IGF-I) concentration in Angus beef cattle, Domest. Anim. Endocrin., 11, 281-290, 1994.

SAS: SAS, Version 14.3, SAS Institute Inc., SAS Campus Drive, Cary, NC 27513-2414, 2017.

Spicer, L. J., Buchanan, B. A., Chapin, L. T., and Tucker, H. A.: Effect of exposure to various durations of light on serum insulinlike growth factor-I in prepubertal Holstein heifers, Am. J. Anim. Vety. Sci., 2, 42-45, 2007.
Squires, E. J.: Applied animal endocrinology, CABI Publishing, ISBN 0-85199-594-2, USA, 234 pp., 2003.

Stuart, J. A. and Page, M. M.: Plasma IGF-1 is negatively correlated with body mass in a comparison of 36 mammalian species, Mech. Ageing Dev., 131, 591-598, 2010.

Suttie, J. M., Breier, B. H., Gluckman, P. D., Littlejohn, R. P., and Webster, J. R.: Effects of melatonin implants on insulin like growth factor 1 in male red deer (Cervus elaphus), Gen. Comp. Endocr., 87, 111-119, 1992.

TSE: Animal feed-metabolic (convertible) energy determinationchemical method. Turkish Standards Institution, TS 9610, Ankara, 1-5, 1991 (in Turkish).

Van Soest, P. J., Robertson, J. B., and Lewis, B. A.: Methods for dietary fiber, neutral detergent fiber, and nonstarch polysaccharides in relation to animal nutrition, J. Dairy Sci., 74, 3583-3597, 1991. 